\title{
THE EFFECT OF TOTAL QUALITY \\ MANAGEMENT IMPLEMENTATIONS ON HOSPITAL PERFORMANCE IN TURKEY
}

\author{
Asena Tuğba EVREN SUBAŞI \\ Near East University, North Cyprus
}

\section{Introduction}

Definition of the Total Quality Management (TQM) is a process that every department and every employees of the organization are get involved and all requirements are carried out by administration for optimum service and production. And in this direction together with to offer quality goods and services, TQM is a management regime which look out for customer demands and satisfaction, worker's requirements and organizational benefits ${ }^{1}$.

According to Schermehom ${ }^{2}$ TQM focuses on human concept apart from technical factors and intend high quality supply to reach customer satisfaction and get into the employees to processes in accordance with the approach of continuous development. In this regard a structure which all of the organization and customers are roled in, must be create. The main difference of TQM from other management approaches is the placement of

\begin{tabular}{|c|c|c|}
\hline (cc) & 12 & $\begin{array}{r}\text { (1) } 2021 \text { The Authors. This is an open-access article } \\
\text { distributed under the terms of the Creative Commons } \\
\text { Attribution License. }\end{array}$ \\
\hline
\end{tabular}


human in the focus of the processes. Through to this property of TQM has performed successful implementations.

According to Slack ${ }^{3}$ the other important factor of the successful of TQM is to set the reliable communication between departments of organizational management. Due to the effect of the every process and proceeding in the organization to other departments of the organization, communication of the organization must be in optimum level from lower level to upper stage and processes must sustain in this sense.

\subsection{Relationship Between Total Quality Management and Performance}

Nowadays, organizations are faced with non-stop changing and developing proceeds associated with technology, globalisation and severe competition. These changing proceeds emerge having regard to focus on human and customer needs with the effect of technological improvements. According to Kıngir ${ }^{4}$ the main factor of the sustainability and competiveness of organizations in these processes is internalization of TQM successfully.

Employee performance and organizational performance are seen the main objectives of TQM because of human oriented approach of it. Most important point is to train every employees permanently and evaluate these employees about effects of work and education which they have taken. Within the scope of TQM, there are different dimensions of performance assessment. Some of them express like teamwork, openness to inovations, elasticity and statistically control and auditing operations. There are some principles on performance-oriented assessments in terms of TQM.

- $\quad$ Efficiency and quality approach that focused on customer and employee of TQM must be placed to performance understanding of organization with continuous improvement philosophy. And bring TQM principles to forefront when determine the all levels and departments of organization. Criterions of the performance assessments should be determined as quality, innovation and efficiency.

- $\quad$ Objectives in the existence, vision, values and missions of an organization should be redefine on behalf of development of performance in accordance with dimensions of efficiency, quality and inovation and aims in the long run should perform clearly. Than by making proper plans and implements, purposes in the short run and medium term should be determine. This process is a basis of performance assessment systems.

- $\quad$ The most important subject in the auditing and assessment of performance is receiving the feedbacks correctly. To be able to transform 
the data, which is obtained from the system, into implementation and decision, evaluation data should forward to right units and employees in optimum time and the developers should be included in these process.

- Indications and assessments of performance is a critical initiator to improvement of performance. Award systems for meeting the success needs of employees and organization could be efficient if only do proper and fair to indications and evaluations.

- $\quad$ Performance outputs should involve whole organization and also the lowest units should be include as long as possible. Measurements and evaluations should be designed and implemented accordingly to TQM.

Other parties in the organization said that instead of the management focus on employees, they need to focus on work process and general businesses. Cardy and Carson ${ }^{5}$ had examined views that generated between TQM and performance evaluation and expressed businesses, which follow blindly TQM, are tend to faulty practices, they should establish a balance between TQM and performance development.

\subsection{Total Quality Management Practices in Hospitals}

The differences of TQM in the perception of companies being expressed that cooperation of management, employees and patients to improve good and services quality in hospitals. ${ }^{6}$

According to Yalçin ${ }^{7}$ in the hospitals TQM is explained that provide world class technological equipment and orientations for fulfilment of patient needs like proper diagnosis, treatment and nursing services and realization of requests.

As a result of wrong treatment complaints and convert of this situation to judicial cases in USA at 1970s, interest on TQM has increased in hospitals and helath services day by day. Focus of TQM which had started to implement in health services for 1980s, is provide 'patient satisfaction' and measure of feedbacks from patients. ${ }^{6}$ After this term TQM focused on efficient diagnosis and nursing services, establish an environment of confidence between patients and employees, motivation of employees, constant improvement approach, high efficiency and receiving the requirements. ${ }^{8}$

In the process of the determining the quality in hospitals, after the appealing of patients, diagnose and realize the proper implements to this diagnosis by technology and science oriented, put forth the technical quality. Physical qualifications of corporation, level of employee and quality of the used equipment are in the technical quality concept. Feelings of patients and | www.ejsr.org 
perceived quality according to received service and improvement of technical quality effect both employee and patient satisfaction directly lead to increase in service quality and performance. As a result of this, according to Söyük and Yenidikici ${ }^{8}$ both profitability and efficiency increase.

According to $\mathrm{Aktan}^{9}$ quality concept in health services is an aim that can realize by TQM. In accordance with this approach management aims to improve goods and service quality with the process including management and organization leader by focusing on human. In hospitals TQM is a manner of rule that aims to create quality assurance system standarts along with quality plan, quality development and quality implements. This definition should be summarize that to satisfy patient satisfaction and happiness. All implements that intend to patient satisfaction like physical conditions of hospital, relationship with employees, pricing, correct diagnosis and treatment methods are the main purposes of the TQM in hospitals.

\subsection{Dimensions of Total Quality Management in Hospitals}

Quality dimensions in hospitals and health services has been studied by several researchers in different ways. In terms of the Kaya ${ }^{10}$ there are three quality dimensions in health services. These are customer quality, professional quality and management quality. Customer quality is assessment of patients about service that meet their demands. Profeesional quality can explain that evaluation of professionalism of health service methods and procedurs. Management quality is controlling the processes and using the resources optimum before, during and after the health care services.

According to Maxwell ${ }^{8}$ there are six dimensions of quality in health services. These are, effectiveness, acceptableness, efficiency, accessibility, fairness and convenience.

Effectiveness is assessment of how effective of the result of diagnosis and treatment. In this point answers of the questions like, is the best treatment available to patient and is this treatment effective on the patient, put forth the quality and achievement of health care services.

Acceptableness is concerning to way of health care services. Considerations of patients about services, communication style of workers, qualifications of the service building with emphasis on privacy and confidentiality are the assessment criterias of acceptableness.

Efficiency is an condition of minimum input for optimum output or as maximum output as from the inputs. Result of comparison to another hospital about cost of care services should provide assessment of efficiency. 
Accessibility is an evaluation of the extent to health service which do not meet an obstacle or interruption at requested time and place. Fairness is an evaluation of to realize of fair treatment opportunities for all patients. Convenience should explain to evaluate of to what extent the health care services meet expectations of individuals considering the needs and all expectations.

Çoruh ${ }^{11}$ cited from A. Donabedian who is the initiator of the quality approach in health sector, seven base dimensions of quality in health. These dimensions include "legality" unlike Maxwell's dimensions. According to Öznalbant ${ }^{12}$ to assess of these dimensions present the value and degree of quality in hospitals.

\subsection{The Effect of Total Quality Management on Hospital Performance}

According to Rust ${ }^{13}$ TQM is directly effect to organizational performance by decreasing the cost of corporations, provide customer satisfaction and loyalty, attracting patients to their institutions rather than competitors and increasing the profitability.

Powell ${ }^{14}$ reported that in terms of organizational performance, TQM, profitability and marketshare improve the organizational performance qualifications. Study of Douglas and Judge ${ }^{15}$ expressed the direct relation between TQM and performance enhancement. The main goals of hospitals besides human dimension are decreasing the costs, profitability, sustainability and enrichment of brand name by achieving growth.

In this point hospitals need TQM due to performing the techonological and labor-intensive service and the necessity of be open to continuous innovation and development ${ }^{16}$. In order to achieve these objectives, attract the employees to education, increase the worker participation to decisions and maket he brand loyalty by obtain customer satisfaction. Especially in private hospitals strategic plans effect organizational performance directly. The important factors of affecting the organizational performance are structure of TQM concept and education. To solve the problems ocur in management of hospitals which is rapidly developing in Turkey, improve the service quality, apply the strategic plans, enter the foreign investment to increase profitability are the effecting factors of organizational performance in sustainable business.

Particularly in hospitals, perform in a quality conditions motivation and productivity of workers will be increase. Tutar ${ }^{17}$ reported that associated with the improvement of working conditions, the job satisfacton of the employees who make their job happier increase. This situation results that can be associated with performance. Working conditions that improved | www.ejsr.org 
every unit by TQM, increase the organizational commitment of workers. Even employees who are dissatisfied showed organizational commitment and started to work more efficiently along with the TQM approach. In this sense, hospital workers is willing to work and do not think different jobs.

TQM practices that carried out in hospitals and other health facilities aim strengthening and developing the institutional structure. Hospital workers maintain more positive business life with elimination of errors in business processes and increasing the efficiency of them. In addition to this contributions of TQM practices to hospital employees and organization the organization provide more willing to work.

According to Yaman ${ }^{18}$ motivated and willing work of hospital staff raising their attention levels and this situation reduce the possibility of error to optimum levels. In this sense that can express organizational and individual performance situations are directly related with TQM practices.

\subsection{Selected Countries for TQM Applications in the World Health Sector}

Russia, France, Germany and South Korea whose started TQM applications simultaneously with Turkey, the applications of these countries implemented within the scope of TQM are mentioned in this part of study.

Russia: Standardization workings about total quality had started at 1917 in Russia. In 1923 regulation about quality control and standart of import goods had started to develop and during the secon world war standardization desks had been established. In that times the importance which is given to industrialization and machine construction, lead up to preparing of quality standarts. While total quality regulations has been starting in 1955, systems associated with the quality of good and increasing of productivity in regard to these sectors had developed. After the 1980s, preparation of new and national quality standarts which enable to improve product systems technically had started and current total quality applications was founded ${ }^{19}$. Health Reform Programme(Zdraw Reform-ZRP) workings had started in 1993 and these reform workings constituted on three basis factors. These factors are;

- $\quad$ To carry out reforms in organizations and health care and treatment financing

- $\quad$ Improve the quality of care services

- On behalf of to meet the necessities which are mentioned above facilitate to establish health information systems. 
Along with the health reform in Russia, applications that shortening the hospitalization period of patients, doing research about provide patient satisfaction, minimization of errors in surgery and ensuring quality approach in hospital management are at the forefront ${ }^{10}$.

France: In France, which started its quality applications during the Second World War like Russia, the health system operates with a system based on patient satisfaction. An organization called ANDEM established with the support of French government in order to carry out effective implementations in health reforms. This organization was established to improve quality, to ensure the regulation and improvement of health services. Targets determined in projects which carried out with the help of ANDEM by identification of processes within the health system, standardization studies on quality, improvement and development activities, evaluating the results that obtained and spreading the benefits throughout the country ${ }^{10}$. In the health system which is close to perfection in terms of health expenditures with gross domestic product, patients have become the key elements in the quality practices of public and private health institutions providing health services. Along with the high level funding provided by state outpatient care and inpatients will take treatment and nursing services. In addition to this special applications and paid treatments realize in private hospitals. According to occupational and income status in France, every citizen is automatically registered in an insurance policy. Apart from that ten percent of population buy complementary health insurance policies for specifik conditions. The first particular case is all patients have to have health insurance. Nobody can cancel or health insurance or withdraw the system. When we look at the quality approach in the management of hospitals, there is an effective internal audit system within all health institutions. NHI, which is also in practice in France like Medicare in USA, focuses on patient satisfaction. But in this system within the permission of hospital management, patients have opportunity to pay directly doctors. French NHI represents "Medicare for All" system in the USA generously by financing and organization of health care and additional private insurances ${ }^{20,21}$.

Germany: DRG which is a health insurance system implemented in Germany is a mechanism based on a system of diagnostic groups. With this system as implemented in Germany using determined diagnostic groups based on comparable treatment costs that aims a patient classification system that allows selective classification of treatment cases. This patient classification system is based on to provide the most appropriate treatment fort he patients according to the requirements and the quality oriented management and working system ${ }^{22}$. 
South Korea: The top authority about regulation and auditing of health system and quality studies is Health and Welfare Ministry in South Korea. Operations related to health insurance and services are carried out under the supervision of this ministry. National Health Insurance Organization which is established under the Health and Welfare ministry, undertakes supporting health insurance associations, guiding to integration of quality applications to health system and make a deal with hospitals for being auditor. In South Korea, citizens prefer to receive treatment or care in large city hospitals instead of micro health agencies even if they have ailments and little diseases or wounds because in these hospitals services are more corporate and qualified. There fore this situation creates an inefficient system for distrust to micro clinics along with offering of health services. In this direction, there is an important quality difference between big cities and rural area. Therapeutic health services are in same weight in South Korea like Turkey. However, despite the differences between rural preventive health services it can be said to be more important. South Korea has a helath system based on welfare-oriented inssurance. This raises a health system in South Korea where all resources, including human resources are used more efficient and effectively ${ }^{23}$.

\subsection{The Effect of TQM Applications on Oncology Service Performance}

When considering medically, quality measurements determine whether optimal treatment approach is applied for patient. From the perspective of quality improvement, whether the goal is achieved in a treatment process or when evaluated the no efficient execution according to specified action limits, quality measurements will be more powerful. Nowadays, especially in radiation oncology, medical errors and quality improvement concern come to the fore. In daily practice of radiation oncology to assess precautions, benefits and stability of quality and security workings are watched always. Safety and quality are different but interrelated issues. Quality in health services is important to specify practices which in terms of achieve the results necessary to improve patient care and safety ${ }^{24}$.

TQM aims improving the conditions and medical equipment in oncology services as in every unit of health care organization. Patients in the oncology services have severe psychological processes than other disease types and they undergo treatment stages tiresomely. In this regard the diagnosis of the disease in oncology correctly and providing optimal treatment opportunities that can be possible by using equipments and devices which are suitable and integrated with technology. 
For oncology services, follow most proper technology, chosing of medical equipments, and supply these equipments, and maintain the using of these in operation, and the periodic maintenance of equipments are directly related with the TQM applications.

In oncology along with the advancing technology diagnosis with less error, hospital workers that open for improvement and can be reach the current information take an important place in treatment of oncology patients. In this respect quality expectation of oncology patients increase. In oncology TQM aims ${ }^{1}$;

- Use of high-cost devices properly

- Perform technical maintenance of the devices periodically and provide local units fort his maintenances.

- $\quad$ Looking out for cost and application balance

- Measurable performance in oncology services

- Coordination with the quality policies of health corporations.

\section{Methodology}

\subsection{Purpose of the Study}

Purpose of the study is to present total quality management applications innovation concept which started to become widespread in health sector on different countries like Turkey, Russia, South Korea, Germany and France, and the contributions of TQM to hospital performance. The other purpose of the study is to determine comparatively variables about hospital performance and values of those countries by years. Thus, in the study data which is published by OECD has been analyzed.

\subsection{Model of Study}

Panel data model was preferred for study. Panel data model is an regression model for panel data. Assumptions of regression analysis is applicable fort this model. In this model units have seperate parameters according to times. In this regard the results of classical regression analysis can not be obtained because the number of parameters to be estimated is greater than the number of obsevations. There fore the model is formed with different assumptions considering the caharacteristics of panel data and error terms. There are two useful panel data model which are fixed effects model and random effects model ${ }^{25}$.

Fixed Effects Model

$$
Y_{i t}=\alpha_{1} D_{1}+\ldots \ldots .+\alpha_{N} D_{N}+X_{i t} \beta+\varepsilon_{i t}
$$




$$
\begin{aligned}
& \text { Random Effects Model } \\
& Y_{i t}=\beta 1_{i t}+\beta 2_{i t}+\ldots \ldots+\beta k_{i t} X k_{i t}+\varepsilon_{i t}
\end{aligned}
$$

\subsection{Data of Study}

The data used in the research has the feature of panel data. In econometric analysis types of data series are cross-sectional series, times series and panel data ${ }^{26}$. According to Güriş ${ }^{25}$ time series and cross-sectional series are different each other. Because time series line up to time variable and do not change the sequence on the other hand cross-sectional series can change and do not line up. In this situation panel data model analyze both time series and cross section series in one. This feature of panel data model is the data type have both horizontal and vertical dimension ${ }^{26}$. In short the difference of these data change according to time besides units. This feature of model can analyze both time and units and prevent the complications. In this study units of the model are the countries which are Turkey, Russia, South Korea, Germany and France. In respect to literature review total quality practices in health sector has started in those countries recently to Turkey. Kaya ${ }^{10}$ reported that, in 1996 French Ministry of Health had started to second continued quality improvement project, quality specialists had studied about hospital management in Germany, health reform programme had started in Russia at 1993, in South Korea some studies had been realized about this topic at 1997. In Turkey quality management directorate established at 1998. In this sense data are taken between 2000 and 2015 years belongs to Turkey, Russia, South Korea, Germany and France. In the study data taken from OECD and TÜIK. Name of the variables are "number of beds per 1000 patient", "number of doctors per 1000 patient", "number of nurses per 1000 patient", "number of MR devices per 100.000 person", "hospitalization time(day)" and "life time after birth".

There is no missing observation among the data used in research. Independent variables are number of beds per 1000 patient(NBP), number of doctors per 1000 patient(NDP), number of nurses per 1000 patient(NNP) and number of MR devices per 100000 person(NMRP) in this research. Dependent variables in the research are hospitalization time(per day)(HD) and life time after birth(LTB). At the beginning of the 2000s along with the increased emphasis on total quality in Turkey, increase in health reforms than establish of Performance Management and Quality Improvement Department within the Ministry of Health also increased the total health expenditures. Changes of total health expenditures by years demonstrated at the table below. 
As shown in Table 2, especially in 2000 total health expenditure had a significant increase of $\% 65$ compared to the previous year. Later on this increase continued in various proportions until today.

As it is seen in Figure 1, NBP, NDP, NNP and NMRP has increased various ratios since 2000 until 2015. Along with the increase of the total health expenditure, share of the units that NBP, NDP, NNP and NMRP in health expenditures also increased. Therefore, those variables were chosen as independent variables of the study. To select dependent variables of study, qualification the HD and LTB like an output of the performance of hospitals and health reforms was decisive. Statistics belong to dependent and independent variables are demonstrated in Table 3.

The averages of the dependent and independent variables for each country used in the study between the years 2000-2015 are demonstrated in the Table 4.

\subsection{Analysis of Data}

Firstly multicollinearity problem which is the assumption of regression method, tested. Whether to detect multicollinearity between dependent variables Tolerance and VIF values summarized and demonstrated below.

According to Table 5, VIF(Variance Inflation Factor) values of independent variables are lower than 10 . Thus, there is not multicollinearity problem within these variables. Regression analysis with panel data was used in this study. First of all for each dependent variables fixed effect model and random effect model was created. For these two separate models non-significant independent variables were excluded and fixed and random effect models are calculated repeatly. The basis method of to generate fixed effect model is within estimator method. According to Güriş ${ }^{25}$ in within estimator method changes in dependent variable can examine by changes in independent variable.

The basis method of to generate random effect model is least square method. According to Güriş ${ }^{25}$ the significant property of least square method is differentiation of error terms according to variance-covariance matrix. After the generate of the models, Hausmann test is applied to determine which one will be chosen. Thereafter fixed variance, autocorelation and cross-sectional dependence of the model were tested.

\section{Findings}

Firstly fixed effect models and random effect models created for dependent variables which are HD and LTB. As the model coefficients are | www.ejsr.org 
analyzed according to units one-way fixed effect model an one-way random effect model was applied. When one-way fixed effect model was installed, Dummy Variable Model was used which stability coefficient changes, slope coefficient remains constant. When one-way random effect model was installed, error component model was used. Outputs of the models demonstrated on the Table 6 .

Table 6 demonstrated that while there are non-significant independent variables in fixed effect model for hospitalization, all independent variables are significant in random effect model. There are both non-significant independent variables for both random and fixed effect model for life time after birth. Models were repeated after non-significant variables excluded from analysis.

In the second step of study, findings of one-way fixed effect model and one-way random effect model, results of Hausman Test, Adjusted Wald Test, BaltagiWu LBI test and Pesaran CDLM to test cross-sectional dependence demonstrated Table 7.

In regard to informations shown at Table 7, due to determine the effect of NBP, NDP, NNP, NMRP variables to hospitalization time, Hausman Test used to create fixed effect and random effect models. According to the results of the Hausman Test, the assumptions of the random effect model did not meet. Therefore study continued with the fixed effect model. Adjusted variance problem occur in model but cross-sectional dependence not. R-squared value is \%96. According to results only NMRP variable has an significant effect on hospitalization. Increase in number of MR devices per person is reducing the hospitalization time.

Due to determine the effect of NBP, NDP, NNP and NMRP variables on Life Time After Birth variable, Hausman Test was used to create fixed effect and random effect model. Results of the Hausman Test showed that the assumptions of the random effect did not meet.

Therefore study continued with the fixed effect model assumptions. Adjusted variance problem occur in model but cross-sectional dependence not. R-squared value is \%84. Results show that NMRP variable has a significant effect on life time after birth. Increase in number of MR devices per person is extend the life time after birth.

\section{Conclusion}

In the context of research, in order to present health expenditures which increased result of the total quality applications in Turkey, Russia, South Korea, Germany and France between 2000-2015, effect to hospital 
performance on variables that hospitalization time, life time after birth, number of beds per 1000 patients, number of doctors per 1000 patients, number of nurses per 1000 patients, number of MR devices per 100000 devices.

As a result of the study NBP, NDP and NNP has not significant effect on LTB. According to obtained results NMRP has significant effect on hospitalization time. With reference to this increase in MR devices extend the life time after birth. According to Akgün and Al-Assaf ${ }^{27}$ in particular the intensive implementation of protective health services has made hospitals more important, both the number of patients in need of treatment and the number of patients in treatment process decreased and than the accessibility of hospitals increased. It has been revealed in various studies, improvements realized as a result of the spread of total quality practices along with the understanding of innovation in health sector has positive effect to various processes of hospitals. A research done by $\mathrm{Gök}^{29}$ with the participation of 100 hospital employee showed that increase of total quality applications has positive effect to raise of the employee productivity and make them more successful about time management. Likewise Gürbüz ${ }^{28}$ conducted a research with 410 staff working in a private hospitals in Ankara and as a result of this research it was determined that perception of leadership, trust and personal relationship from total quality management elements significantly effected individual performance of health staffs. In consequence of study NBP, NDP and NNP have no significant effect on hospitalization time. According to results NMRP has significant effect on hospitalization time. Thus increase in MR devices per 100000 person reduce the hospitalization time.

As a result of the Küçük's ${ }^{30}$ study which done upon to total quality management by the participation of 500 patient, the primary factors that have positive effects on patient satisfaction are service structure of hospitals and hardware facilities. Seyhan ${ }^{31}$ studied on supply process of magnetic resonance devices in public hospitals and the satisfaction of users of device. In the research conducted in public hospitals operating in Ankara, as a result of view of staff supply of new technologies facilitate the operations performed in hospitals and ease of use is higher than the old devices.

In accordance with this information, in this study increase in NMRP reduce the hospitalization time. From this point of view, throughout the process until today quality improvements in hospital provide technical strengthening of hospitals, technically empovered hospitals are becoming easier, thus it is concluded that there is a significant decrease in hospitalization time. 
Magnetic Resonance is a effective method uses nowadays to detect prostatic adenocarcinoma, breast neoplasms, dimensions of heart diseases, brain neoplasms and paralyze with neural system. Evaluation of the results of study NMRP significantly effect hospitalization time and life time after birth. Hence for further studies research on technical opportunities which is effective on diagnosis level and treatment level affect on hospital performance are recommended.

\section{Disclosure statement}

No potential conflict of interest was reported by the author. 


\section{References and notes:}

Karabulut, F. (2009). Sağlık İşletmelerinde Kalite ve Akreditasyon ISOUEC 15189:2003 Uygulamas1, Yüksek Lisans Tezi, T.C. Dokuz Eylül Üniversitesi Sosyal Bilimler Enstitüsü Toplam Kalite Yönetimi Anabilim Dalı, İzmir.

Schermehorn, Jr J. R., Hunt, J.G., \&Osborn, R.N. (2000). OrganizationalBehavior, John Wiley\&SonsInc, New York, U.S.A.

Slack, N., Chambers, S., \&Johnston, R. (2001). Operations Menagement, PrenticeHall, London

Kıngır, S., Karagöz, Y., Yıldız, M. S., \&Ağraş, S. (2009). Toplam Kalite Yönetimi İle İlgili Çalışmalara Katılım Düzeyinin Belirlenmesine Yönelik Bir Araştırma, Atatürk Üniversitesi Sosyal Bilimler Enstitüsü Dergisi, Say1:13, ss.255-278.

Cardy, R. L., \&Carson, K. P. (1996). Total qualityandtheabandonment of performanceappraisal: Taking a goodthingtoofar?. Journal of Quality Management, 1(2), 193-206.

Çavuş M. F., \& Gemici, E. (2013). Sağlık Sektöründe Toplam Kalite Yönetimi, Akademik Sosyal Araştırmalar Dergisi, TheJournal of AcademicSocialScience, 1(1), 238-257.

Yalçın, N. (2014). Sağlık Kuruluşlarında Kalite ve Akreditasyon Açısından Tıbbi Kayıt Sistemine Yaklaşımlar Yüksek Lisans Tezi, T.C. Dokuz Eylül Üniversitesi Sağl1k Bilimleri Enstitüsü, İzmir

Söyük S., \&Yenidikici A.Ü. (2010). Sağlık Kurumları İşletmeciliği Önlisans Programı Sağlık İşletmelerinde Kalite Yönetimi, İstanbul Üniversitesi Açık ve Uzaktan Eğitim Fakültesi, 1. Baskı, İstanbul.

Aktan C. C. (1999). Yeni Yönetim Tekniklerinin Kamu Yönetiminde Uygulanması, Türk İdare Dergisi, (1), 425.

Kaya, S. (2003). Çeşitli Ülkelerdeki Hastanelerde Uygulanan Toplam Kalite Yönetimi/Sürekli Kalite İyileștirme Çalışmalarından Örnekler, Amme İdaresi Dergisi, 36(4), 83-101.

Çoruh, M. (1995). Birinci Basamak Sağlık Hizmetlerinde Toplam Kalite Yönetimi, Ankara, 23-28.

Öznalbant, Z. (2010). Sağlık Sektöründe Hizmet Kalitesi Ölçümü ve Bir Uygulama, Afyon Kocatepe Üniversitesi Yayınları, No:77, Ankara.

Rust, R. T., Zahorik, A. J., \&Keiningham, T. L. (1994). Return on quality: Measuringthefinancialimpact of yourcompany'squestforquality. Probus Publishing Company.

Powell, T.C., (1995). Total Quality Management as Competitive Advantage: a ReviewandEmpiricalStudy, Strategic Management Journal 16, 15-37.

Douglas, T.J., Judge, W.Q. (2001) Total Quality Management İmplementationandCompetitive Advantage: The Role Of Structural Control And Exploration, Academy of Management Journal 44-1, 158-69.

Sitimalakorn, W., Hart, S. (2004) Marketing OrientationVersusQualityOrientation: Sources of Superior Business Performance, Journal of Strategic Marketing, 12 (December), 243-253.

Tutar, H. (2007). Erzurum'da Devlet ve Özel Hastanelerde Çalışan Sağlık Personelinin İşlem Adaleti, İş Tatmini ve Duygusal Bağlılık Durumlarının İncelenmesi”, Süleyman Demirel Üniversitesi İktisadi Ve İdari Bilimler Fakültesi, 12(3), 97120.

Yaman, Y. (2013). Toplam Kalite Yönetimi ve Sağlik Sektörü, Yüksek Lisans Tezi, Beykent Üniversitesi Sosyal Bilimler Enstitüsü, İstanbul.

Asgarov, K. (2007). Rusya'da Toplam Kalite Yönetimi Sisteminin Gelişimi, Mevcut Durumu ve Uluslararası Kalite Yönetim Sistemiyle Karşılaştırılması, Yüksek Lisans Tezi, T.C. Dokuz Eylül Üniversitesi Sosyal Bilimler Enstitüsü, İzmir. 
Imai, Y., Jacobzone, S., \&Lenain, P. (2010). TheChangingHealthSystem in France. Paris, France: EconomicsDepartment, OrganizationforEconomicCooperationand Development; November. WorkingPaper 268.

OECD Health Data. (2017). OrganizationforEconomicCooperationand Development, 18. CarnetsStatistiques, Paris.

Schreyögg, J., Tiemann, O., \&Busse, R. (2007). The DRG ReimbursementSystem in Germany,,EuroObserver, Winter 2005, Volume 7, Number 4, C. Çetin Değer (çev.), Makro Bakış, 5,29.

Sargutan, E. (2014). Almanya Sağlık Sistemi, Ülkelerin Karşıllaştırmalı Sağlık Sistemleri, 139-174.

Pawlicki, T.,Chera, B., Ning, T., Marks, L.B.., (2012). TheSystematic Application Of QualityMeasuresAndProcess Control in ClinicalRadiationOncology.Semin RadiatOncol. 22(1):70-6. doi: 10.1016/j.semradonc.2011.09.006.

Güriş, S. (2015). Panel Veri ve Panel Veri Modelleri. In S. Güriş, Stata ile Panel Veri Modelleri (pp. 1-37). İstanbul: Der Yayınları.

Kutlar, A. (2017).EViews ile Uygulamalı Zaman Serileri, Umuttepe Yayınları

Akgün, S., \& Al-Assaf, A. F. (2007). Sağlık Kuruluşlarında Hasta Güvenliği Anlayışını Nasıl Oluşturabiliriz?, Sağlık Düşüncesi ve Tıp Kültürü Dergisi, 3, 42-47.

Gürbüz, F. (2014). Toplam Kalite Yönetimi Algısının Bireysel Performansa Etkileri Üzerine Sağlık Çalışanları Uygulaması, Yüksek Lisans Tezi, Ufuk Üniversitesi, Sosyal Bilimler Enstitüsü, Ankara.

Gök, D. (2014). Toplam Kalite Yönetimi Uygulamalarının Özel Sağlık Kuruluşlarında İş Verimliliği Üzerine Etkisi: Elazığ Medikal Park Hastanesi Örneği, Yüksek Lisans Tezi, Türk Hava Kurumu Üniversitesi, Sosyal Bilimler Enstitüsü, Ankara.

Küçük, N. (2009). Sağlık Hizmetlerinde Toplam Kalite Yönetimi Ve Dış Müşteri Memnuniyeti Üzerine Diyarbakır İl Sağlık Müdürlügü’nde Bir Uygulama (Diyarbakır Devlet Hastanesi), Yüksek Lisans Tezi, Cumhuriyet Üniversitesi Sosyal Bilimler Enstitüsü, Sivas.

Seyhan, F. (2014). Kamu Hastanelerinde Kullanılan Manyetik Rezonans Cihazlarının Tedarik Süreci Ve Cihaz Kullanıcılarının Memnuniyetinin Değerlendirilmesi, Yüksek Lisans Tezi, Türk Hava Kurumu Üniversitesi, Sosyal Bilimler Enstitüsü, Ankara. 


\section{Table Legends}

Table 1. Variables of study

Table 2. Changes in total health expenditures by years for Turkey

Table 3. Brief statistics of dependent and independent variables

Table 4. Averages of dependent an independent variables according to countries

Table 5. Multicollinearity test values of independent variables

Table 6. First step models

Table 7. Second step models

\section{Figure Legends}

Figure 1. Change of NBP, NDP, NNP, NMRP by years for Turkey

\section{Table 1. Variables of study}

\begin{tabular}{|c|c|l|l|l|}
\hline No & Independent variables & $\begin{array}{l}\text { Variable } \\
\text { Name }\end{array}$ & Dependent variables & $\begin{array}{l}\text { Variable } \\
\text { Name }\end{array}$ \\
\hline 1 & number of beds per 1000 patient & NBP & & \\
\hline 2 & number of doctors per 1000 patient & NDP & & \\
\hline 3 & number of nurses per 1000 patient & NNP & & \\
\hline 4 & Number of MR devices per 100000 person & NMRP & & \\
\hline 5 & & & $\begin{array}{c}\text { hospitalization } \\
\text { time(per day) }\end{array}$ & HD \\
\hline 6 & & & life time after birth & LTB \\
\hline
\end{tabular}

Table 2. Changes in total health expenditures by years for Turkey

\begin{tabular}{|c|c|c|}
\hline \multirow{2}{*}{ Yıl } & \multicolumn{2}{|c|}{ Toplam Sağlık Harcaması } \\
\cline { 2 - 3 } & Milyon TL & Değişim Oranı \\
\hline 2000 & 8248 & $65 \%$ \\
\hline 2001 & 12396 & $50 \%$ \\
\hline 2002 & 18774 & $51 \%$ \\
\hline 2003 & 24279 & $29 \%$ \\
\hline 2004 & 30021 & $24 \%$ \\
\hline 2005 & 35359 & $18 \%$ \\
\hline 2006 & 44069 & $25 \%$ \\
\hline 2007 & 50904 & $16 \%$ \\
\hline 2008 & 57740 & $13 \%$ \\
\hline 2009 & 57911 & $0.3 \%$ \\
\hline 2010 & 61678 & $7 \%$ \\
\hline 2011 & 68607 & $11 \%$ \\
\hline 2012 & 74189 & $8 \%$ \\
\hline 2013 & 84390 & $14 \%$ \\
\hline 2014 & 94750 & $12 \%$ \\
\hline 2015 & 104568 & $10 \%$ \\
\hline
\end{tabular}


Table 3. Brief statistics of dependent and independent variables

\begin{tabular}{|l|l|l|l|l|}
\hline & Minimum & Maksimum & Average & Std. Deviation \\
\hline NBP & 2.08 & 11.59 & 7.15 & 2.85 \\
\hline NDP & 1.30 & 5.00 & 2.98 & 1.18 \\
\hline NNP & 1.06 & 13.30 & 5.90 & 3.65 \\
\hline NMRP & 0.78 & 33.63 & 10.80 & 9.07 \\
\hline HD & 3.90 & 14.00 & 8.13 & 2.72 \\
\hline LTB & 71.10 & 80.00 & 76.40 & 2.10 \\
\hline
\end{tabular}

Table 4. Averages of dependent an independent variables according to countries

\begin{tabular}{|l|l|l|l|l|l|}
\hline & Turkey & Germany & French & Russia & Korea \\
\hline NBP & 2.51 & 7.66 & 6.95 & 8.46 & 10.17 \\
\hline NDP & 1.57 & 1.81 & 3.30 & 3.62 & 4.61 \\
\hline NNP & 1.42 & 4.28 & 4.28 & 11.78 & 7.71 \\
\hline NMRP & 5.89 & 16.16 & 6.05 & 23.46 & 2.45 \\
\hline HD & 4.68 & 10.09 & 5.79 & 8.55 & 11.54 \\
\hline LTB & 74.08 & 75.81 & 77.63 & 77.25 & 77.25 \\
\hline
\end{tabular}

Table 5. Multicollinearity test values of independent variables

\begin{tabular}{|l|l|l|l|}
\hline \multicolumn{2}{|c|}{} & Tolerance & VIF \\
\hline \multirow{4}{*}{ Independent variables } & NBP & .350 & 2.859 \\
\cline { 2 - 4 } & NDP & .141 & 4.088 \\
\cline { 2 - 4 } & NNP & .139 & 5.213 \\
\cline { 2 - 4 } & NMRP & .240 & 4.161 \\
\hline
\end{tabular}


Table 6. First step models

\begin{tabular}{|c|c|c|c|c|}
\hline & \multicolumn{2}{|c|}{$\begin{array}{l}\text { hospitalization time(per } \\
\text { day) }\end{array}$} & \multicolumn{2}{|c|}{ life time after birth } \\
\hline & $\begin{array}{l}\text { Sabit Etki } \\
\text { Modeli }\end{array}$ & $\begin{array}{ll}\text { Rassal Etki } \\
\text { Modeli }\end{array}$ & \begin{tabular}{|l|} 
Sabit Etki \\
Modeli
\end{tabular} & $\begin{array}{ll}\text { Rassal } & \text { Etki } \\
\text { Modeli } & \end{array}$ \\
\hline \multirow[t]{2}{*}{ NBP } & .064656 & 1.037037 *** & -.028892 & -.018275 \\
\hline & .071887 & .098006 & .112755 & .083650 \\
\hline \multirow[t]{2}{*}{ NDP } & .532497 & 2.641878*** & -.348454 & $2.358802 * * *$ \\
\hline & .420767 & .373480 & .659978 & .318772 \\
\hline \multirow{2}{*}{ NNP } & -.093296 & $.792103 * * *$ & .158326 & $-.543347 * * *$ \\
\hline & .268655 & .121507 & .421389 & .103708 \\
\hline \multirow[t]{2}{*}{ NMRP } & $-.156710 * *$ & $-.277883^{* * *}$ & $.300206 * *$ & $.235160 * * *$ \\
\hline & .055006 & .037132 & .086177 & .031693 \\
\hline F Değeri & $27.48 * * *$ & & $48.64 * * *$ & \\
\hline $\begin{array}{l}\text { Wald Ki Square } \\
\text { Değeri }\end{array}$ & & $196.75 * * *$ & & $147.28 * * *$ \\
\hline
\end{tabular}

Table 7. Second step models

\begin{tabular}{|c|c|c|c|c|}
\hline & \multicolumn{2}{|c|}{$\begin{array}{l}\text { Hastanede Kalış Süresi } \\
\text { (Gün) }\end{array}$} & \multicolumn{2}{|c|}{$\begin{array}{l}\text { Doğumdan Sonra Beklenen } \\
\text { Yaşam Süresi }\end{array}$} \\
\hline & $\begin{array}{l}\text { Sabit Etki } \\
\text { Modeli }\end{array}$ & $\begin{array}{l}\text { Rassal Etki } \\
\text { Modeli }\end{array}$ & $\begin{array}{lr}\text { Sabit } & \text { Etki } \\
\text { Modeli } & \end{array}$ & \begin{tabular}{|ll} 
Rassal & Etki \\
Modeli &
\end{tabular} \\
\hline \multirow[t]{2}{*}{ NBP } & & $\begin{array}{l}1.037037 * * \\
*\end{array}$ & & \\
\hline & & .098006 & & \\
\hline \multirow[t]{2}{*}{ NDP } & & $\begin{array}{l} \\
2.641878 * * \\
*\end{array}$ & & $2.318583^{* * *}$ \\
\hline & & .373480 & & .258609 \\
\hline \multirow{2}{*}{ NNP } & & $.792103 * * *$ & & $-.540551 * * *$ \\
\hline & & .121507 & & .102269 \\
\hline \multirow[t]{2}{*}{ NMRP } & $\begin{array}{l}- \\
.170868 * * \\
*\end{array}$ & $.277883 * * *$ & $.306713^{* * *}$ & $.232869 * * *$ \\
\hline & .018303 & .037132 & .021901 & .029718 \\
\hline F Değeri & $54.47 * * *$ & & $196.12 * * *$ & \\
\hline $\begin{array}{l}\text { Wald Ki Square } \\
\text { Değeri }\end{array}$ & & $196.75 * * *$ & & $149.10^{* * *}$ \\
\hline Hausman Testi & $10.62^{* * *}$ & & $13.51 * * *$ & \\
\hline $\begin{array}{l}\text { Değiştirilmiş } \\
\text { Wald Testi }\end{array}$ & $549.25 * * *$ & & $1061.39 * * *$ & \\
\hline
\end{tabular}

| www.ejsr.org 


\begin{tabular}{|l|l|l|l|l|} 
Durbin-Watson & .325089 & .581230 & \\
\hline $\begin{array}{l}\text { BaltagiWu LBI } \\
\text { Testi }\end{array}$ & .709166 & .936863 & \\
\hline Pesaran CD & -1.548 & .943 & \\
\hline $\mathrm{R}^{2}$ & .960 & .835 & \\
\hline F Değeri & $293.43^{* * *}$ & & $75.05^{* * *}$ & \\
\hline
\end{tabular}

Figure 1. Change of NBP, NDP, NNP, NMRP by years for Turkey

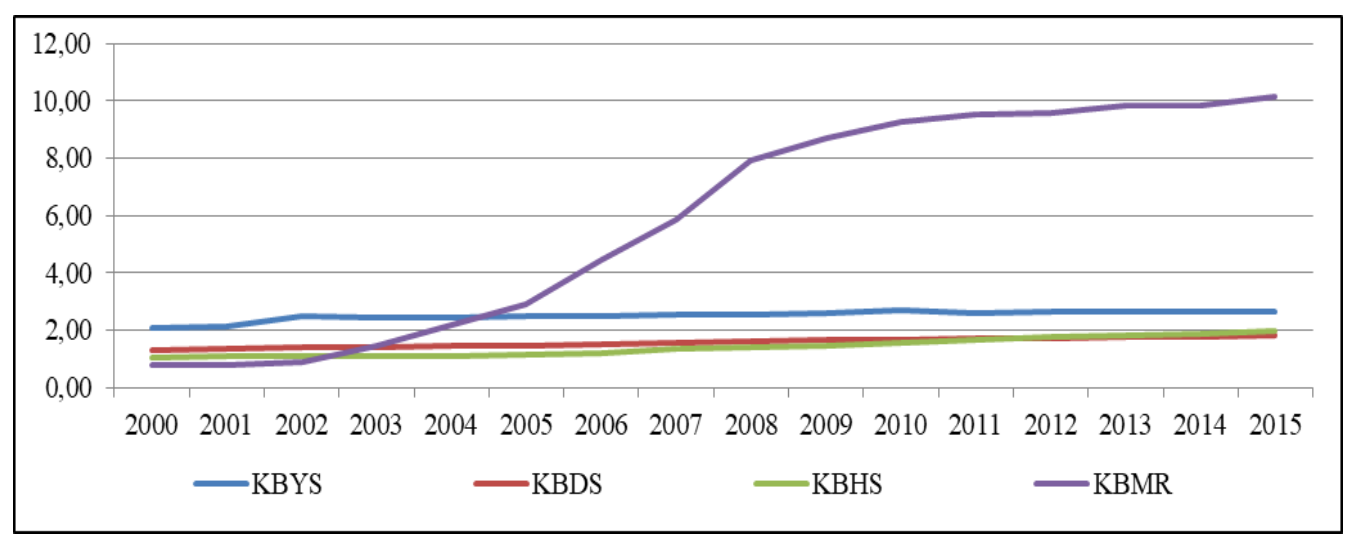




\title{
ÖZET
}

\section{Toplam Kalite Yönetimi uygulamalarının Türkiye'de hastane performansina etkisi}

\author{
Asena Tuğba EVREN SUBAŞI \\ Yakın Doğu Üniversitesi, Kuzey Kıbrıs Türk Cumhuriyeti
}

\begin{abstract}
İlk olarak sanayi sektöründe uygulamaya konulan ve faydası görülen kalite kavramı hizmet sektöründe de uyguamaya konulmuştur. Sağlık sektöründe ise hasta odaklılık, çalışan katılımı gibi Toplam Kalite uygulamalarının alt konuları ile uygulamaya geçiş sağlanmıştır. Hasta beklentilerinin tahmini ve hizmete kolay erişilebilirlilik ile memnuniyetinin sağlanması, hasta tarafından tercih edilebilirlilik, hasta sadakati ve gelen hasta sayısındaki artışı amaçlayan hastaneler aynı zamanda çalışanların memnuniyeti ve hızlı teşhis, doğru tedavi uygulaması ile kurum performansını arttırmayı amaçlamaktadırar. Hastanede kalış süresinin azaltılması ile hasta giriş çıkışlarının hızlanması ile hizmet verilen hasta sayısında artış sağlanması ve doğğumdan sonra beklenen yaşam süresi üzerinde olumlu etkisi olması beklenmektedir.
\end{abstract}

Araştırmanın amacı sağlık alanında yoğunluk kazanan ve yaygınlaşan toplam kalite yöntemi uygulamalarının, hastanelerin performansına sağladığı katkının ortaya konmasıdır. Bu amaçla Türkiye, Rusya, Kore, Almanya ve Fransa olmak üzere ülkelerde hastanede kalış süresi ve doğumdan sonra beklenen yaşam süresi üzerinde etkili olarak faktörlerin belirlenmesi için panel veri analizi yöntemi uygulanmıştır. Araştırma sonucunda hastanede kalış süresi (gün) ve doğumdan sonra beklenen yaşam süresi üzerinde 100,000 kişi başına düşen MR görüntüleme ünitesi sayısının anlamlı bir etkisinin olduğu gözlenmiştir.

Anahtar Kelimeler: Toplam Kalite Yönetimi, Hastane Performansı, Panel Veri Analizi, Hastanede Kalış Süresi, Beklenen Yaşam Süresi 


\title{
РЕЗЮМЕ
}

\section{Влияние практики тотального управления качеством на работу больниц в Турции}

\author{
Асена Тугба ЭВРЕН СУБАШИ \\ Ближневосточный университет, Турецкая Республика Северного Кипра
}

\begin{abstract}
Концепция качества, которая впервые была реализована на практике в промышленном секторе и принесла пользу, была также реализована на практике в сфере услуг. В секторе здравоохранения переход был достигнут с под темами практики полного качества, такими как ориентация на пациента и участие сотрудников. Больницы, нацеленные на оценку ожиданий пациентов и удовлетворение их легкой доступностью к услуге, предпочтением пациента, лояльностью пациентов и увеличением количества поступающих пациентов, также стремятся повысить эффективность работы учреждения с удовлетворением сотрудников, быстрой диагностикой и правильное применение лечения. Ожидается, что сокращение продолжительности пребывания в больнице, ускорение входа и выхода пациентов, увеличение количества обслуживаемых пациентов и положительное влияние на ожидаемую продолжительность жизни после рождения.
\end{abstract}

Целью исследования является выявление вклада практик общего качества, которые стали интенсивнее и получили широкое распространение в области здравоохранения, в работу больниц. С этой целью был применен метод анализа панельных данных для определения факторов, влияющих на продолжительность пребывания в больнице и ожидаемую продолжительность жизни после рождения в таких странах, как Турция, Россия, Корея, Германия и Франция. В результате исследования было замечено, что количество аппаратов МРТ на 100000 человек существенно влияет на продолжительность пребывания в больнице (дни) и ожидаемую продолжительность жизни после рождения.

Ключевые слова: общее управление качеством, эффективность работы больницы, анализ панельных данных, продолжительность пребывания в больнице, ожидаемая продолжительность жизни. 